\title{
A Fast and Robust FTIR-ATR Coupled Chemometric Determination of Chemical and Molecular Structure of Wheat (Triticum aestivum L.) under a Series of Microbial Fermentation Processes
}

\author{
Sulhattin YASAR ${ }^{1}$, Ramazan TOSUN ${ }^{2}$ \\ ${ }^{1}$ Faculty of Engineering, Department of Food Engineering, Karamanoglu Mehmetbey University, Yunus Emre \\ Yerleşkesi, Karaman, 70100, Turkey \\ ${ }^{2}$ Faculty of Agriculture, Department of Animal Science, Igdir University, Şehit Bülent Yurtseven Kampüsü, Suveren, \\ Igdir, 76000, Turkey \\ *Corresponding author: S. Yasar e-mail: sulhattin.yasar@gmail.com
}

RESEARCH ARTICLE

\begin{abstract}
This study aimed to ferment wheat grain by optimised bacteria, yeast and fungal fermentations. Crude protein, tannin, phytic acid and lactic acid contents of samples taken at $24 \mathrm{~h}$ intervals determined by chemical methods were compared with those of infrared (IR) spectro-chemometry. Secondary protein components were further quantified with IR spectra deconvolution method. The results indicated that some fermentations increased crude protein of wheat, whilst its tannin and phytic acid degraded in all fermentations. Wheat enriched with lactic acid content in all fermentations. FT-IR spectroscopic method accurately $(99.99 \%$ of recovery) and precisely (regression coefficient of prediction $\mathrm{R}^{2}=0.999, \mathrm{P}<0.0001$ ) predicted these nutrient contents. Fermentation positively caused a re-organised secondary protein conformation; the percentages of $\beta$-sheet and $\alpha$-helix increased by 68 and $140 \%$, respectively, whereas the random coil decreased by $63 \%$. FT-IR spectrometry combined with suitable chemometric tools provided a fast and robust monitoring of chemical and structural changes during microbial fermentation.
\end{abstract}

Keywords: FTIR-ATR spectroscopy; microbial fermentation; secondary protein components; wheat.

Received: 15 August 2020 Accepted: 26 November 2020 Published: 15 May 2021

DOI:

10.15835/buasvmcn-asb:2020.0016

\section{INTRODUCTION}

Wheat grain (Triticum spp.) is an important dietary ingredient for the nutrition of human and mono-gastric animals by serving a source of carbohydrates, proteins, minerals and vitamins. It is well known that anti-nutritional factors (ANF) present in wheat grain can lower protein digestibility and bioavailability of other nutrients to animals and human beings. Therefore, the elimination or degradation of endogenous ANF by the means of physical, chemical and microbial treatments is necessary (Sarwar Gilani et al., 2012).

We previously demonstrated that microbial fermentation lowered ANF contents of foods and caused an enzymatic, antioxidant and organic acid enrichment (Yasar and Tosun, 2018). The conditions of temperature, $\mathrm{pH}$, pressure and stirring in microbial fermentation are milder than that of a heat or chemical treatment wherein harsh conditions of food processing may cause undesirable Maillard reaction, yielding oxidised forms of amino acids (Sarwar Gilani et al., 2012). On the other hand, optimising $\mathrm{pH}$, stirring rate, moisture level and temperature depending on the type and strain of microorganisms used and the expected outcome at the end of fermentation greatly affects the efficacy of microbial solid state fermentation using modern bioreactor (Yasar and Tosun, 2018; Karakurt et 
al., 2019). However, microbial fermentation is not always expected to result in both adding functionalities and causing nutritional fortifications. For instance, Lactobacillus plantarum fermentation significantly lowered most of the ANF in pea protein concentrate, while its in vitro protein digestibility was lowered from 67.0 to $54.6 \%$, mostly in the increased content of sulfur containing amino acids (Cabuk et al., 2018). In contrary, a recent study from our laboratory (Yasar and Tosun, 2018) demonstrated that an optimised microbial fermentation greatly changed the nutritional composition of barley grain by increasing the level of crude protein and decreasing the level of ANF (mainly dietary fibre and phytic acid) in comparison to its raw unfermented form. In addition, the fermented barley had modified secondary protein components (SPC) which was broadly determined from second derivate data of Fourier transform infrared attenuated total reflectance (FTIR-ATR) spectra, and was added with new bio-molecules such as enzymes and antioxidants which was observed as new peaks in the spectra. Thus, the quality of a plant protein subjected to the fermentation process could be improved by degrading ANF negatively affecting in vivo and in vitro protein digestibility. In the above study, a univariate statistical analysis was used to qualitatively quantify the differences in chemical and molecular structure between the fermented and unfermented sample of barley. It was previously well documented that the protein quality can be improved in the form of changed SPC by food processing (Salazar-Villanea et al., 2016). Changing SPC can increase the accessibilities of enzymes during in vitro or in vivo protein digestion (Salazar-Villanea et al., 2016). We hypothesised that the fermentation is a food processing treatment involved in metabolic and chemical processes and can affect SPC of a given substrate. Yasar and Tosun (2019) recommended an accurate model based on second derivate of the treated FT-IR spectra with baseline corrections, normalisation, smoothing and multiplicative scatter correction in order to demonstrate only a single case of how the secondary protein structure of barley grain differed from its fermented counterpart. But, the prediction model was a univariate statistical regression model and only tested with a single microorganism and a single food material. We further hypothesised that a model can be developed using a multivariate analysis of partial least square regression (PLSR) and tested in a series of microbial fermentation processes involving the use of bacteria, fungi and yeast microorganisms.

FTIR-ATR spectroscopy generally provides a spectral pattern of a sample resembling its chemical composition (Wubshet et al., 2017) and it can be coupled with chemometry and used to quantify molecular structures and chemical composition (Carbonaro et al., 2012; Wilcox, 2014). The method precision can be improved by proper data handling and transformation (Yasar and Tosun, 2019). Native protein conformation is characterised by the shape of regular hydrogen bonds between amide and carboxyl groups of a polypeptide and can be defined as $\alpha$-helixes, $\beta$ pleated sheets, $\beta$-turns and unfolded (random coil) structures (Salazar-Villanea et al., 2016). The authors provided a good review on the effects of some food processing factors (heat, shear rate, moisture level) on SPC determined by FTIR-ATR spectroscopy. We hypothesised that fermentation by the use of bacteria, yeast, fungi may have an effect on SPC. In our best knowledge, there are no other studies developing and testing the robustness of FTIR-ATR spectro-chemometric method on wheat grain fermented by several types of microorganisms (bacteria, yeast and fungi). Monitoring nutritional and chemical composition of a food subjected to fermentation by spectrochemometry could be of significant use for the fermentation industry.

The objective of the study was to determine the changes made on native protein conformation of wheat grain subjected to a series of optimised fermentation processes using bacteria, yeast and fungi, and to predict chemically determined contents of crude protein, some ANFs and lactic acid production by FTIR-ATR spectroscopy combined with a multivariate regression analysis, PLSR.

\section{MATERIALS AND METHODS}

\section{Cultivation of microbial inoculants}

The strains of bacteria, fungi and yeast used in this study were generally regarded as safe (GRAS), and obtained from DSMZ (Deutsche Sammlung von Microorganismen und Zellkulturen $\mathrm{GmbH}$ ) as freeze-dried. Aspergillus oryzae

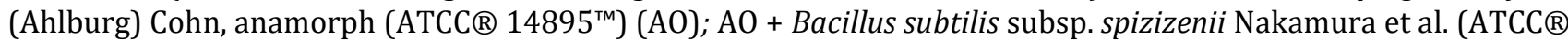
$6633^{\mathrm{TM}}$ ) (C+D); Lactobacillus salivarius subsp. salicinius Rogosa et al. (ATCC ${ }^{8} 11742^{\mathrm{TM}}$ ) (LBS) and Saccharomyces cerevisiae Meyen ex E.C. Hansen (ATCC $® 9080^{\mathrm{TM}}$ ) (SC) were cultivated to collect fungal spores, bacteria and yeast cells under conditions specified by the provider' instructions. The collected inoculants were suspended in an $8 \%$ ( $w$ $\mathrm{v}^{-1}$ ) saline buffer solution and enumerated on Neubauer chamber as well as by reading its absorbance at $600 \mathrm{~nm}$ (Genesys TM 10S UV-VIS, Thermo Scientific, USA). Then their concentrations were cross-confirmed by the determination of colony forming unit (cfu) per mL using official methods of analysis, namely ISO 15787:2009 (2009) for bacteria, ISO 15788:2009 (2009) for yeast, and ISO 21527-1:2008 (2008) and ISO 21527-2:2008 (2008) for fungi. The suspensions with exact known quantities of inoculants are used in each fermentation experiment (Table 1). Samples were enumerated as colony forming units to monitor microbial growth in every $24 \mathrm{~h}$ of fermentations (Table 1). 
Table 1. Experimental set up of microbial fermentations

\begin{tabular}{|c|c|c|c|c|}
\hline Fermentation conditions & AO & $C+D$ & LBS & SC \\
\hline $\begin{array}{c}\text { Inoculant (per g wet } \\
\text { sample) }\end{array}$ & $1.5 \times 10^{6}$ spore & $\begin{array}{c}C=7.5 \times 10^{7}+D=3.7 \\
\times 10^{6} \text { spore }\end{array}$ & $2.4 \times 10^{5} \mathrm{CFU}$ & $2.5 \times 10^{8} \mathrm{CFU}$ \\
\hline pH & $4.0-5.0$ & $4.0-7.0$ & $5.1-5.5$ & 5.5 \\
\hline Moisture level, \% & 85.00 & 60.00 & 60.00 & 75 \\
\hline $\mathbf{T},{ }^{\circ} \mathbf{C}$ & $24-28$ & $26-34$ & $32-38$ & $24-28$ \\
\hline Sampling intervals, $\mathrm{h}$ & $0,24,48,72$ & $0,24,48,72$ & $0,24,48$ & $0,24,48,72,96,120$ \\
\hline Stirring rate, rpm & 150 & 10 & 90 & 10 \\
\hline Aeration rate, $\mathrm{L} / \mathrm{min}$ & 1.5 & 0.2 & 0.5 & 0.2 \\
\hline
\end{tabular}

\section{Fermentation studies}

A local cultivar of Gerek-79 of wheat grain (Triticum aestivum L.) was obtained from a wheat producer, and ground to pass a $3 \mathrm{~mm}$ sieve before autoclaving at $121^{\circ} \mathrm{C}$ for $15 \mathrm{~min}$. For each fermentation study, freshly autoclaved wheat was transferred into a sterilised $\left(175^{\circ} \mathrm{C}\right.$ for $\left.60 \mathrm{~min}\right)$ solid state bioreactor with $3.5 \mathrm{~L}$ working capacity of Labfors $5^{\text {TM }}$ (Infors AG, Bottmingen, Switzerland). The moisture content of fermenting substrate was adjusted by using sterilized distilled water, and its $\mathrm{pH}$ by sterilized buffer solutions of $0.1 \mathrm{M}$ sodium acetate $(\mathrm{pH}=1.5)$ and $0.1 \mathrm{M}$ sodium bicarbonate $(\mathrm{pH}=9.75)$ through peristaltic pumps. The experimental set-up was provided in table 1 . The best fermentation conditions for each microorganism such as moisture content, $\mathrm{pH}$ and temperature were selected from an extensive literature review and then fixed at the start of fermentation experiments (Azza et al. 2013, Yu-ling et al. 2013; Zhang et al., 2014). The $\mathrm{pH}$ and temperature were optimised by stirring and aeration rate not fixed at the beginning of the fermentation (Table 1). The sterilised filters of $0.25 \mu \mathrm{m}$ were mounted on inlets and outlets. The amount of released $\mathrm{CO}_{2}(0 \%$ to $100 \%), \mathrm{CH}_{4}(0 \%$ to $100 \%)$ and $\mathrm{H}_{2} \mathrm{~S}$ (1 to $1000 \mathrm{ppm}$ ) was detected by a bio-gas detector (SA2Q from Beijing ShiAn Technology Instrument C0., Ltd). Ethanol and nitrogen were collected on bottles containing boric acid and acid dichromate solution, respectively, at a $24 \mathrm{~h}$ interval and determined by a titrimetric method (Karabulut and Canbolat, 2005).

\section{Chemical analysis}

Three independent samples taken at every $24 \mathrm{~h}$ were dried $<50^{\circ} \mathrm{C}$ and ground to pass a $1-\mathrm{mm}$ sieve. Chemical analysis was carried out in triplicates for each of three independent samples, providing a total of 9 independent measurements per incubation period. A titrimetric method reported by Karabulut and Canbolat (2005) determined lactic acid production. An official method of analysis (AOAC, 2016) determined crude protein content (method 984.13). The method described by Chemesova and Chizhikov (2004) determined the content of total tannin, and the method of De Boland et al. (1975) for phytic acid contents.

\section{FTIR-ATR measurements}

In this study, one of the incubation periods was considered as a single experimental unit, for which a total of 192 spectral scans (3 by 64 co-scans) were co-added. Each of three dried samples obtained at the end of each fermentation period was independently ground by a drum mill (DRY-MILL TM 300, Retsch GmbH Germany) to obtain a homogenous sample with particle size of $<20 \mu \mathrm{m}$ prior to the spectrum scanning. FT-IR spectrum of the sample was collected at room temperature by using Agilent Carry 630 FTIR spectrometer (Agilent Technologies Inc., Danbury, CT, USA) fitted with a diamond attenuated total reflectance (ATR) sample interface by co-adding 64 scans at every $4 \mathrm{~cm}^{-1}$ frequencies over a band range of 380 to $700 \mathrm{~cm}^{-1}$. The spectrum was corrected during scanning for a background spectrum simultaneously. Spectral data of amide I (1600 to $\left.1700 \mathrm{~cm}^{-1}\right)$ and II region (1480-1600 $\mathrm{cm}^{-1}$ ) were baseline corrected, normalised and smoothened to determine peak absorbance area of amide I and II bands and the ratio of amide I to II. The second derivate of normalised and standardised absorbance value (a.u) from individual bands at every $4 \mathrm{~cm}^{-1}$ within the range of 650 to $1900 \mathrm{~cm}^{-1}$ were regressed with the analysed concentrations of crude protein, total tannin, phytic acid and lactic acid concentrations of the samples over a range of fermentation period by a PLSR using Minitab statistical programme (Minitab ${ }^{\circ}$ 17.1.0 Minitab Inc., 2013) to predict the chemically analysed data. The processed data set of 192 spectra for each incubation period was randomly introduced to a PLSR model so that a $2 / 3$ of the data was used as a calibration data set and the remaining as independent validation data set to be an unknown sample. The model is based on a leave-one-out cross validation and then prediction of unknown samples. This continued until a minimum RESSCV (residual sum square of cross 
validation) and RMSECV (Residua mean square of cross validation) were found. The model was then applied to the cross validation data set to predict the nutrient concentrations with highest regression coefficient of cross validation $\left(\mathrm{R}^{2}\right)$. The band ranges used in the generation of PLSR models were specifically selected for each of organic compounds from the literature review (see the results and discussion section). The second derivate of original spectrum data was reported to be the best predictor in FTIR-ATR spectroscopy (Yasar et al., 2019). The ratio of standard error of the mean (SEM) of the chemically analysed concentration to the standard error of the prediction (SEP) of the PLSR model, regression coefficient of prediction $\left(\mathrm{R}^{2}\right)$ and the accuracy of the method (closeness to the analysed value) were calculated to demonstrate the robustness of the model (Yasar et al., 2019). Furthermore, in order to predict the percentages of each SPC, the baseline corrected and normalised spectral data from the amide I region of 1600 to $1700 \mathrm{~cm}^{-1}$ was subjected to Gaussian curve fitting followed by Fourier self-deconvolution (FSD) using OriginPro 2016 (OriginLab Corporation, Northampton, MA 01060 USA). FSD was first applied to the amide I region to resolve all SPC and to determine their peak frequencies and their widths using asymmetric baseline correction and rescaling treatments. Gaussian curve fitting was then done at lowest Chi-square $\left(\mathrm{X}^{2}\right)$ values on the amide I spectral data using the peak frequencies and widths determined by FSD. This way of spectral deconvolution and curve fitting was applied to the most likely distribution function of independent spectroscopic absorbing processes (Carbonaro et al., 2012). Each of SPC was predicted by a calculation method based on the ratio between the integrated absorbance intensity of each Gaussian fitted component and that of the entire amide I band (1600 to $1700 \mathrm{~cm}^{-1}$ ). The contributions of $\alpha$-helix from 1650 to $1660 \mathrm{~cm}^{-1}, \beta$-sheet from 1630 to $1640 \mathrm{~cm}^{-1}$, unfolded/random coils (RC) from 1640 to $1648 \mathrm{~cm}^{-1}$, $\beta$-turns (T1) from 1660 to $1670 \mathrm{~cm}^{-1}$ and (T2) from 1670 to $1680 \mathrm{~cm}^{-1}$, protein aggregations and absorption of amino acid side chain (A1) from 1610 to $1615 \mathrm{~cm}^{-1}$ and (A2) from 1690 to $1695 \mathrm{~cm}^{-}$ 1 , side chains (S) from 1560 to $1610 \mathrm{~cm}^{-1}, \beta$-sheet intermolecular aggregates ( $\beta$-i) from 1620 to $1630 \mathrm{~cm}^{-1}$ and intramolecular antiparallel $\beta$-sheets $(\beta-\mathrm{a})$ from 1680 to $1688 \mathrm{~cm}^{-1}$ were then calculated. These band ranges were reported by Carbonaro et al. (Carbonaro et al., 2012). Percentages (\% of entire amide I band) of all SPC and ratio of $\alpha$-helix: $\beta$-sheet were compared between fermented and unfermented wheat samples.

\section{Statistical analysis}

Experimental model employed in this study was 4 experiments using AO, C+D, LBS and SC by 4 (0, 24, 48, 72 h), 4 $(0,24,48,72 \mathrm{~h}), 3(0,24,48 \mathrm{~h})$ and $6(0,24,48,72,96,120 \mathrm{~h})$ incubation periods, respectively by 3 independent samples at each incubation period by 3 replicates of chemical analysis or 192 FT-IR spectral measurements (3 samples by 64 scan). A general linear model (GLM) was used to analyse the data (SPSS 15 for Windows, Inc. 2016), and significant differences within each fermentation experiment were separated at $5 \%$ level of significance.

\section{RESULTS AND DISCUSSIONS}

\section{Monitoring fermentation parameters}

The fermentation conditions set-up for each of microbial fermentation experiments was presented (Table 1). The $\mathrm{pH}$ of fermenting substrate was excellently fixed at 5.0 which was an average of fixed range. There was a significant increase in $\mathrm{pH}$ from 5.0 at $48 \mathrm{hr}$ to 6.9 at $72 \mathrm{hr}$ of AO fermentation. Microbial growth reached peak levels by $24 \mathrm{~h}$ fermentation, and thereby remained unchanged. Microbial growth increased 1 to 3 Log 10 CFU per gram in AO, C+D and LBS fermentation, while there was only an increase of 0.5 Log10 CFU in SC fermentation. This pattern of microbial growth was parallel to the pattern of $\mathrm{CO}_{2}$ production which was the highest at $24 \mathrm{hr}(1 \%$ in $\mathrm{AO}, 4 \%$ in $\mathrm{C}+\mathrm{D}, 6 \%$ in LBS and 4\% in SC), thereby gradually decreased. Furthermore, organic acids produced by microbial fermentation such as lactic acid in our study (Table 2) have a negative impact on microbial growth by $48 \mathrm{hr}$ fermentation (Karakurt et al., 2019). In general, the efficacy of fermentation can greatly be influenced by the type of microorganism used, temperature, $\mathrm{pH}$ and the rates of aeration and stirring (Krishna, 2005). In our study, the temperature was perfectly regulated at the fixed values by arranging the suitable rates of aeration and stirring. Therefore, these factors were only controlled to stabilize the temperature at the fixed value since any unintended raise in the temperature may negatively denature protein of the substrate (Santos et al., 2004). Thus, the differences in the rates of stirring and aeration between the fermentation experiments (Table 1) are inevitable since the temperature was perfectly controlled by changing its rate.

\section{Nutritional composition}

Fermentation of wheat by AO significantly ( $\mathrm{P}<0.05$ ) affected its nutritional composition (Table 2). The crude protein content was significantly $(\mathrm{P}<0.05)$ increased by $7.2 \%$ from $11.66 \%$ at $0 \mathrm{~h}$ to $12.23 \%$ at $42 \mathrm{~h}$ and $12.50 \%$ at $72 \mathrm{~h}$ (Table 2). Similarly, tannin and phytic acid significantly $(\mathrm{P}<0.05)$ reduced throughout fermentation. Reduction rates in tannin and phytic acid contents were over $70 \%$. On the other hand, AO fermentation caused a marked production $(\mathrm{P}<0.05)$ of lactic acid, particularly at 24 and $48 \mathrm{~h}$. The lactic acid production raised by 5.3 -folds as compared to the lactic acid content of unfermented wheat samples (Table 2). Using AO fungi in food fermentation at similar conditions as in our study resulted in a 13 to $180 \%$ increase in crude protein which was higher than that of $7.2 \%$ increase in our study, and a 30 to $66 \%$ reduction in tannin and a 35 to $74 \%$ reduction in phytic acid which 
were quite similar to our results (Zhong-Tao et al., 2009). The effect of C+D fermentation on nutrient concentrations of wheat was significant $(\mathrm{P}<0.05)$. Crude protein of wheat was significantly $(\mathrm{P}<0.05)$ reduced from $11.66 \%$ of unfermented wheat to $10.66 \%$ in $24 \mathrm{~h}$ and to $10.94 \%$ at $48 \mathrm{~h}$. The rate of reduced crude protein was $-7.0 \%$.

Table 2. Predictive ability of PLSR model for chemically analysed concentrations of crude protein, tannin, phytic acid and lactic acid production by microbial fermentation of ground wheat grain

\begin{tabular}{|c|c|c|c|c|c|c|c|c|c|}
\hline & \multirow{2}{*}{ Time intervals } & \multicolumn{2}{|c|}{ Crude protein \% } & \multicolumn{2}{|c|}{ Total tannin \% } & \multicolumn{2}{|c|}{ Phytic acid \% } & \multicolumn{2}{|c|}{ Lactic acid \% } \\
\hline \multirow{6}{*}{ AO* } & & $A^{\S}$ & $\mathrm{P}^{\#}$ & $\mathrm{~A}$ & $\mathrm{P}$ & $\mathrm{A}$ & $\mathrm{P}$ & $\mathrm{A}$ & $\mathrm{P}$ \\
\hline & 0 & $11.66^{b}$ & 11.65 & $1.09^{a}$ & 1.08 & $1.92^{\mathrm{a}}$ & 1.91 & $0.31^{c}$ & 0.29 \\
\hline & 24 & $11.72^{\mathrm{b}}$ & 11.70 & $0.39 \mathrm{~b}$ & 0.38 & $1.26^{\mathrm{b}}$ & 1.25 & $1.14^{\mathrm{a}}$ & 1.46 \\
\hline & 48 & $12.23^{\mathrm{a}}$ & 12.18 & $0.36^{\mathrm{b}}$ & 0.36 & $0.64^{c}$ & 0.63 & $1.67 \mathrm{a}$ & 1.65 \\
\hline & 72 & $12.50^{\mathrm{a}}$ & 12.54 & $0.31^{\mathrm{b}}$ & 0.31 & $0.47 \mathrm{~d}$ & 0.46 & $0.84^{\mathrm{b}}$ & 0.84 \\
\hline & 0 & $11.66^{a}$ & 11.65 & $1.09 \mathrm{a}$ & 1.08 & $1.92^{\mathrm{a}}$ & 1.91 & $0.31^{\mathrm{d}}$ & 0.29 \\
\hline \multirow{4}{*}{$\begin{array}{c}\text { C+ } \\
\text { D }\end{array}$} & 24 & $10.86^{b}$ & 10.89 & $0.57 \mathrm{c}$ & 0.56 & $1.32^{\mathrm{b}}$ & 1.32 & $0.83^{c}$ & 0.82 \\
\hline & 48 & $10.94^{b}$ & 10.94 & $0.56^{c}$ & 0.56 & $0.58^{c}$ & 0.59 & $1.89 \mathrm{a}$ & 1.91 \\
\hline & 72 & $11.16^{\mathrm{ba}}$ & 11.14 & $0.86^{\mathrm{b}}$ & 0.86 & $0.42^{\mathrm{d}}$ & 0.41 & $1.24^{\mathrm{b}}$ & 1.24 \\
\hline & $\mathbf{0}$ & $11.66^{a}$ & 11.65 & $1.09^{b}$ & 1.08 & $1.92^{\mathrm{a}}$ & 1.91 & $0.31^{c}$ & 0.29 \\
\hline \multirow[t]{4}{*}{ LBS } & 24 & $16.10^{\mathrm{b}}$ & 16.10 & $3.50^{\mathrm{c}}$ & 3.5 & $1.06^{b}$ & 1.05 & $1.14^{b}$ & 1.08 \\
\hline & 48 & $11.70^{\mathrm{a}}$ & 11.68 & $1.73^{\mathrm{a}}$ & 1.72 & $0.62^{\mathrm{c}}$ & 0.62 & $2.05^{\mathrm{a}}$ & 2.10 \\
\hline & 0 & $11.66^{\mathrm{a}}$ & 11.65 & $1.09^{a}$ & 1.08 & $1.92^{\mathrm{a}}$ & 1.91 & $0.31^{\mathrm{f}}$ & 0.29 \\
\hline & 24 & $10.84^{b}$ & 10.82 & $0.37 \mathrm{e}$ & 0.37 & $1.53^{\mathrm{b}}$ & 1.53 & $0.62^{\mathrm{e}}$ & 0.62 \\
\hline \multirow{4}{*}{ SC } & 48 & $10.67^{b}$ & 10.70 & $0.50^{\mathrm{b}}$ & 0.49 & $1.14^{\mathrm{c}}$ & 1.14 & $1.26^{\mathrm{b}}$ & 1.26 \\
\hline & 72 & $11.26^{\mathrm{a}}$ & 11.23 & $0.51^{\mathrm{b}}$ & 0.50 & $0.84^{\mathrm{d}}$ & 0.83 & $0.93^{\mathrm{d}}$ & 0.93 \\
\hline & 96 & $11.28^{\mathrm{a}}$ & 11.30 & $0.44^{c}$ & 0.44 & $0.52^{\mathrm{e}}$ & 0.51 & $1.04^{\mathrm{c}}$ & 1.04 \\
\hline & 120 & $11.35^{\mathrm{a}}$ & 11.34 & $0.40^{\mathrm{d}}$ & 0.40 & $0.31^{\mathrm{f}}$ & 0.31 & $1.73^{\mathrm{a}}$ & 1.72 \\
\hline & SEM (analysed) & \multicolumn{2}{|c|}{0.25} & \multicolumn{2}{|c|}{0.067} & \multicolumn{2}{|c|}{0.037} & \multicolumn{2}{|c|}{0.125} \\
\hline & SEP (predicted) & \multicolumn{2}{|c|}{0.014} & \multicolumn{2}{|c|}{0.0012} & \multicolumn{2}{|c|}{0.0008} & \multicolumn{2}{|c|}{0.021} \\
\hline & SEM:SEP & \multicolumn{2}{|c|}{18.21} & \multicolumn{2}{|c|}{55.8} & \multicolumn{2}{|c|}{46.8} & \multicolumn{2}{|c|}{5.95} \\
\hline & A \% & \multicolumn{2}{|c|}{100} & \multicolumn{2}{|c|}{100} & \multicolumn{2}{|c|}{100} & \multicolumn{2}{|c|}{99.99} \\
\hline & $\mathbf{R}^{2}$ & \multicolumn{2}{|c|}{0.999} & \multicolumn{2}{|c|}{0.999} & \multicolumn{2}{|c|}{0.999} & \multicolumn{2}{|c|}{0.999} \\
\hline & $\% \mathrm{~V}$ & \multicolumn{2}{|c|}{$99 \%$} & \multicolumn{2}{|c|}{$95 \%$} & & & & \\
\hline & $\mathbf{P}$ & & & & & & & & \\
\hline
\end{tabular}

${ }^{*} \mathrm{AO}=$ Aspergillus oryzae $; \mathrm{C}+\mathrm{D}=\mathrm{AO}+$ Bacillus subtilis; $\mathrm{LBS}=$ Lactobacillus; $\mathrm{SC}=$ Saccharomyces cerevisiae; ${ }^{\S} \mathrm{A}=$ averaged analysed values; ${ }^{\#} \mathrm{P}=$ averaged predicted values; ${ }^{\mathrm{a}-\mathrm{f}}=$ different superscripts indicate significant differences $(\mathrm{P}<0.05)$ between the means of analysed constituents of wheat grain over a period of fermentation within each microorganism in the same coloumn; SEM = standard error of the means; SEP = standard error of prediction; $\mathrm{A}=$ accuracy estimated as closeness of the predicted value to the analysed concentration; $\mathrm{R}^{2}$ = regression coefficient of prediction; $\% \mathrm{~V}=$ percentage of variance explained by the model; $\mathrm{P}=$ probability level indicating the significance level of PLSR model.

There were consistently significant reductions in tannin and phytic acid contents throughout fermentation. The reduction rates of tannin and phytic acids were $-48 \%$ and $-78 \%$, respectively. On the other hand, the production of lactic acids by $\mathrm{C}+\mathrm{D}$ fermentation was 6 -folds. In this experiment a mixed fermentation of $\mathrm{AO}$ (C) plus Bacillus subtilis (D) for wheat was tested to yield utmost nutritional fortification. However, the obtained results on nutritional fortification were similar to that of $\mathrm{AO}$ in this study, with the exception of a higher lactic acid production which could be due to the effect of bacteria (D) in the mixture. Bacillus spp. fermentation generally yielded a 3 to $104 \%$ increase in crude protein and $17 \%$ degradation of dietary fibre and increase in lower molecular protein content of some foods and feeds to some extent (Azza et al., 2013). In contrast, a fungal and bacteria mixed fermentation caused a $7 \%$ reduction in crude protein, but -48 and $-78 \%$ reductions in ANF (tannin and phytic acid) of wheat grain in our study.

LBS fermentation caused significant $(\mathrm{P}<0.05)$ changes on the contents of nutrients. The crude protein increased by $38 \%$, only at $24 \mathrm{~h}$ fermentation from 11.66 to $16.10 \%$. Unlike other microbial fermentation, LBS fermentation caused significantly $(\mathrm{P}<0.05)$ increased tannin content from $1.09 \%$ to $3.5 \%$ at $24 \mathrm{~h}$ and to $1.73 \%$ at $48 \mathrm{~h}$. The increased rate in tannin content was about 1.7 to 3.5 folds. Tannins are available in plants in two different forms; hydrolysable or condensed forms which are composed of flavonoid units, and Adebo et al. (2018) reported an increased hydrolysable forms of tannins in whole grain sorghum seed fermented by Lactobacillus strains. On the other hand, phytic acid had a consistent degradation $(\mathrm{P}<0.05)$ about $67 \%$ by the end of fermentation. LBS 
fermentation caused a significant $(\mathrm{P}<0.05)$ increase in lactic acid production by 6.6 -folds, which was the highest production among the fermentation experiments. There is only a single study conducted by Zhang et al. (2015), indicating LBS fermentation caused a significant increase in crude protein by $40 \%$, mainly as low molecular weight of protein, similar to the increased rate of crude protein in our study. In our study, a $67 \%$ reduction in phytic acid content of wheat grain is a great indication of the fact that fermentation using lactic acid bacteria including LBS are potentially useful in reducing phytates in plant materials (Raghavendra and Halami, 2009; Lopez et al., 2010; Batista et al., 2019).

SC fermentation has a significant $(\mathrm{P}<0.05)$ effect on nutrient components. Significant reductions in crude protein by $-8.4 \%$, in tannin by $-80 \%$ and in phytic acid by $-84 \%$ were found. However, SC fermentation caused a significant $(\mathrm{P}<0.05)$ production of lactic acid by 5.5 -fold. In contrast, Azza et al. (2013) have reported a $75 \%$ increase in crude protein of agricultural and food materials by SC fermentation. Overall, the reduced crude protein concentration in fungal, fungal + bacteria and yeast fermentations in this study was found contrary to earlier results (Zhong-Tao et al., 2009; Azza et al., 2013). The reason may depend on the differences in the strains of microorganisms used in these studies, and further some strains of microorganisms must have needed additional nitrogen source which was not available in our fermentation experiments. In our study, LBS and C+D (bacteria and fungi mixture) has the highest lactic acid production rate by over 6.0 to 6.6-folds respectively, compared to fungal (AO) and yeast (SC) fermentation by 5.0 to 5.5 -fold, respectively. In this study, there was a high rate of degradation of ANF by bacteria, yeast and fungi. These results were in good agreement with previously reported data (Kim et al., 2010), except in the case of LBS fermentation where the tannin has gradually increased. A few bacteria have been reported with tannase activity, but most fungi and yeast are capable of producing tannase enzymes (Mohapatra et al., 2006).

\section{Prediction of chemical contents by PLSR combined FTIR-ATR spectroscopy}

PLRS model used was based on following equation:

$$
\mathrm{Y}=\mathrm{b}_{0}+\mathrm{b}_{1} * \mathrm{X}_{1}+\mathrm{b}_{2} * \mathrm{X}_{2}+\ldots+\mathrm{b}_{\mathrm{p}} * \mathrm{X}_{\mathrm{p}}
$$

where: $\mathrm{Y}=$ nutrient concentration; $\mathrm{b}_{0}$ is regression coefficient of intercept; bi values are regression coefficients (for variables 1 through $\mathrm{p}$ ) computed from the absorbance peaks of ( $\mathrm{X}_{1}$ to $\mathrm{X}_{\mathrm{p}}$ ) over an infrared (IR) spectra range.

In order to improve the method's precision and accuracy the data treatments of baseline correction, normalisation and multiplicative scatter correction of original IR spectra (Figure 1) before it's generation of second derivate were made (Yasar et al., 2019; Yasar et al., 2020). In the model, second derivate of absorbance peaks (a.u) at every $4 \mathrm{~cm}$ 1 intervals over a range of 1500 to $1700 \mathrm{~cm}^{-1}, 650-1850 \mathrm{~cm}^{-1}, 800-1400 \mathrm{~cm}^{-1}$ and $1000-1900 \mathrm{~cm}^{-1}$ was used to predict crude protein, total tannin, phytic acid and lactic acid, respectively. IR region of 1500 to $1700 \mathrm{~cm}^{-1}$ assigned for amide I and II regions for crude protein prediction were selected from early reported data (Yasar and Tosun, 2018).

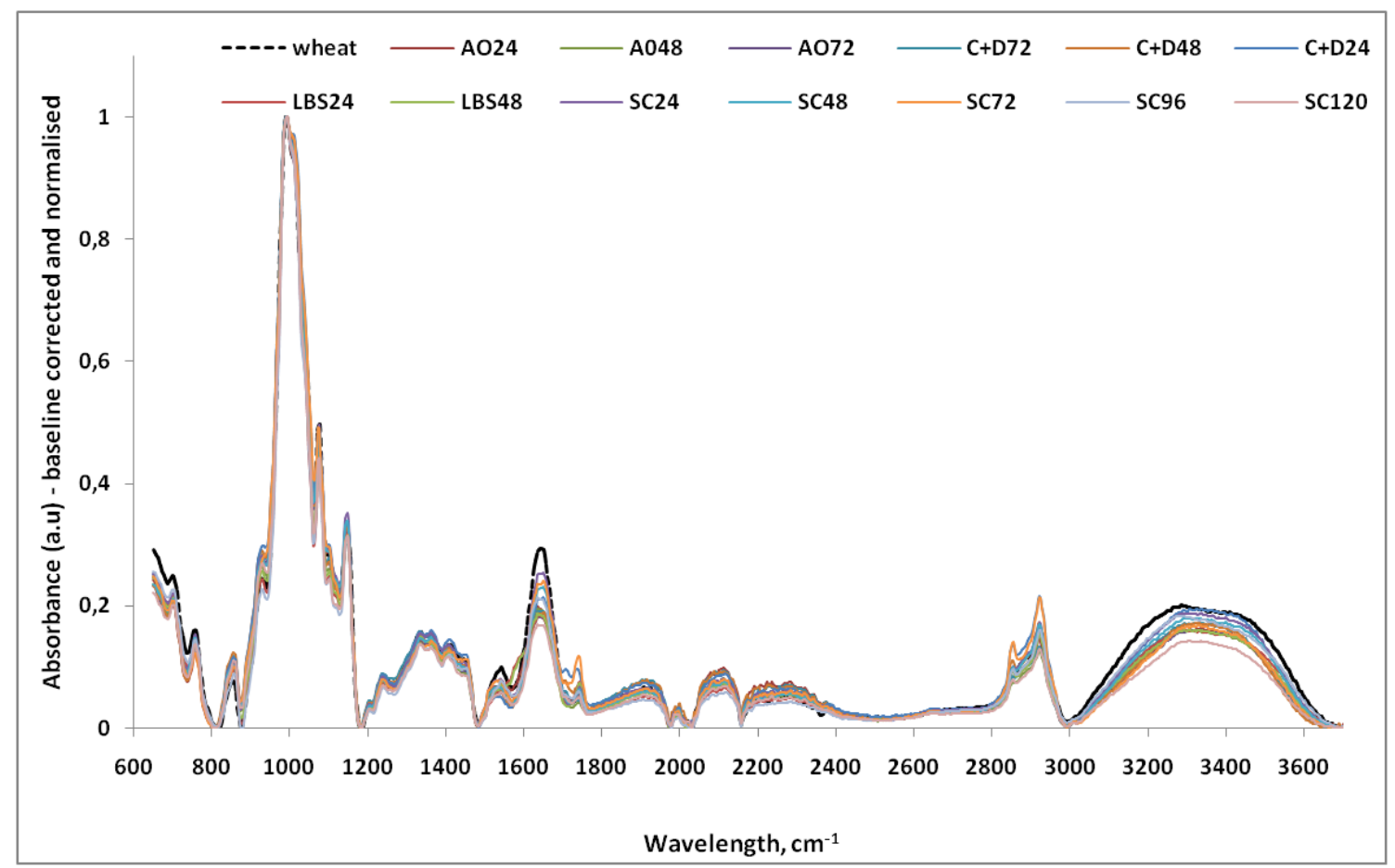

Figure 1. FT-IR spectra of wheat samples from a series of microbial fermentation.

$\mathrm{AO}=$ Aspergillus oryzae $; \mathrm{C}+\mathrm{D}=\mathrm{AO}+$ Bacillus subtilis $; \mathrm{LBS}=$ Lactobacillus salivarius; $\mathrm{SC}=$ Saccharomyces cerevisiae . 
A second derivate IR of amide I and II region was illustrated for all fermentation in Figure 2, where there were clear zones of differentiations between the wheat samples. In Figure 2 some visual differences were observed at 1525, $1542,1553-1583,1602,1617,1635,1670$ and $1685 \mathrm{~cm}^{-1}$ between unfermented and fermented samples, indicating the action of fermentation. Similar results were also found in earlier studies (Carbonaro et al., 2012; Wilcox, 2014; Yasar and Tosun, 2018) in the prediction of crude protein levels, but with higher accuracy values obtained at our study (Table 2). For the prediction of total tannin content, an entire IR band region from 700 to $1900 \mathrm{~cm}^{-1}$ was used in the model due to the fact that several specific bands over this IR range were highly associated with molecular bonds of tannin (Silverstein et al., 1991): a distortion vibration of $C=C$ in benzene rings at $754 \mathrm{~cm}^{-1}$, stretching vibrations of $-\mathrm{C}-\mathrm{C}$ aromatic groups at $1452 \mathrm{~cm}^{-1}$, stretching vibration of $\mathrm{C}=0$ carbonyl groups at $1730-1705 \mathrm{~cm}^{-1}$ and C-0 at $1100-1300 \mathrm{~cm}^{-1}$, aromatic -0- vibrations at $646,800,1050,1165 \mathrm{~cm}^{-1}$ and aromatic $-\mathrm{CH}_{2}-\mathrm{OH}$ vibrations at 1420 and $1452 \mathrm{~cm}^{-1}$. At these IR bands, the differences in second derivate data of tannin between unfermented and fermented samples were quite visible (Figure 3), and tannin contents were precisely and accurately predicted (Table 2). In the literature, it was stated that the band of 800 to $1400 \mathrm{~cm}^{-1}$ was responsible for vibrational absorption of organic phosphorus (P) containing P-O-R groups (Dave and Modi, 2018). Thus, IR band range of 800 to $1400 \mathrm{~cm}$ ${ }^{1}$ was subjected to PLSR analysis. And, there were visible differences in chemical bonds of phytic acid between the samples. Dave and Modi (2018) well predicted phytic acid contents using spectral bands from 800 to $1400 \mathrm{~cm}^{-1}$ by a regression analysis, similar to our method which has higher accuracy and precision characteristics (Table 2). IR band from 1728 to $1732 \mathrm{~cm}^{-1}$ arising from stretching of $\mathrm{C}=0$ of carboxylic acid was found to be associated with organic acids and the band at 1385 to $1397 \mathrm{~cm}^{-1}$ arising from the $\mathrm{O}-\mathrm{H}$ bending of carboxylic acid or $\mathrm{CH}_{3}$ bending with volatile organic acids (Silverstein et al., 1991). A spectral band region from 1000 to $1800 \mathrm{~cm}^{-1}$ was shown to be related with lactic acid in wine (Moreira and Santos, 2005). The differences in all these absorption bands regarding lactic acid between the samples of our study were visible in the second derivate of original IR spectral data (Figure 3 ). Therefore, the analysis of the entire region of 1000 to $1800 \mathrm{~cm}^{-1}$ provided an improved prediction of lactic acid concentrations of wheat samples (Table 2).

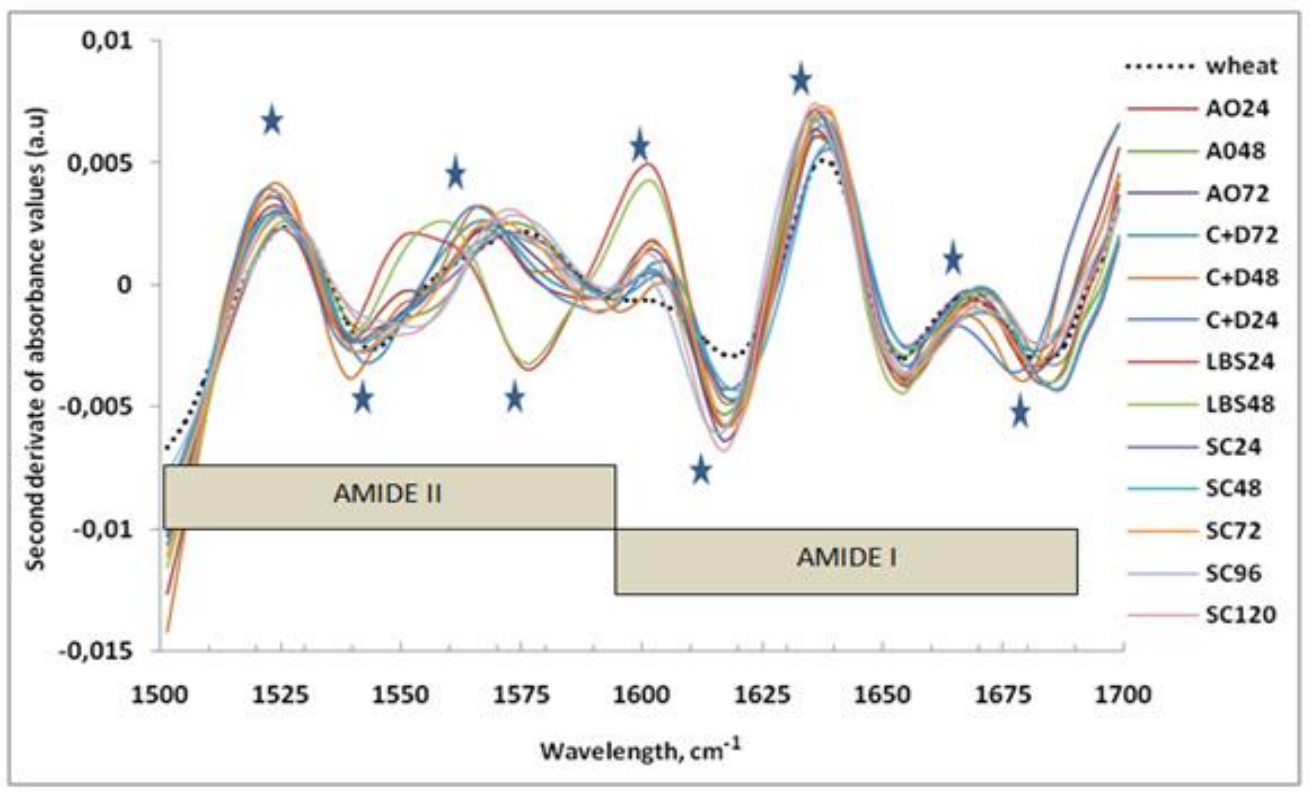

Figure 2. Second derivate of FT-IR spectra data (amide I and II regions from1500 to $1700 \mathrm{~cm}^{-1}$ were shown) subjected to PLSR analysis to predict the chemically analysed protein contents. Annotated star showing remarkable differences during the course of bacterial, fungal and yeast fermentations.

In general, PLSR results (Table 2) showed that the model explained 99.99, 95.00, 98.00 and $98.00 \%$ of total variance for crude protein, total tannin, phytic acid and lactic acid, respectively with a high regression coefficient of determination $\left(\mathrm{R}^{2}=0.99 ; \mathrm{P}<0.0001\right)$. These high $\mathrm{R}^{2}$ values were also obtained from the similar studies with sunflower meal and fermented soybean meal (Yasar et al., 2019; Yasar et al., 2020). Previously, Ferrao and Davanzo (2005) reported high $\mathrm{R}^{2}$ values of 0.98-0.99 for predicting protein and ash content of wheat and Mahesar et al. (2010) accurately and precisely predicted the total trans fat content of cereal-based foods with the $\mathrm{R}^{2}$ values of 0.9991 using a part of whole data during validation was used as independent data set in PLSR model, exactly the same model used in our study. Ishiguro et al. (2003) reported a high $\mathrm{R}^{2}$ value of 0.9991 for ATR-FTIR prediction of phytic acid in soymilk using the same method of prediction used in our study. A similar model of FTIR spectroscopy used to quantify rumen volatile fatty acid levels had a regression coefficient values ranging from 0.9926 to 0.9976 
(Udén and Sjaunja, 2009). Having carefully examined these publications, the method of calibration and validation where $1 / 3$ of samples used as independent data set was a PLSR method providing high precise results. The method performance parameters of SEM:SEP ratio were 18.21, 55.8, 46.8 and 5.95 for crude protein, total tannin, phytic acid and lactic acid, respectively with highest A (accuracy considered as recovery) values of almost $100 \%$. All the ratios of SEM:SEP in our study were above 2 which was considered a good predictive indicator of the selected model (Yasar et al., 2019). FTIR-ATR prediction (1300 to $1750 \mathrm{~cm}^{-1}$ ) of protein concentration subjected to enzymatic hydrolysis provided an accurate and precise determination for several food materials (Wubshet et al., 2017), but the method performance $\left(\mathrm{R}^{2}=0.86-0.94\right)$ was lower than the performance of the method employed in our study $\left(\mathrm{R}^{2}\right.$ $=0.999$ ). The use of second derivate data after spectral data treatments and carefully selection of the specific range of bands for each of the above-mentioned organic compounds played important role to improve the method performance characteristics, as confirming our earlier results (Yasar and Tosun, 2018; Yasar et al., 2019; Yasar et al., 2020).

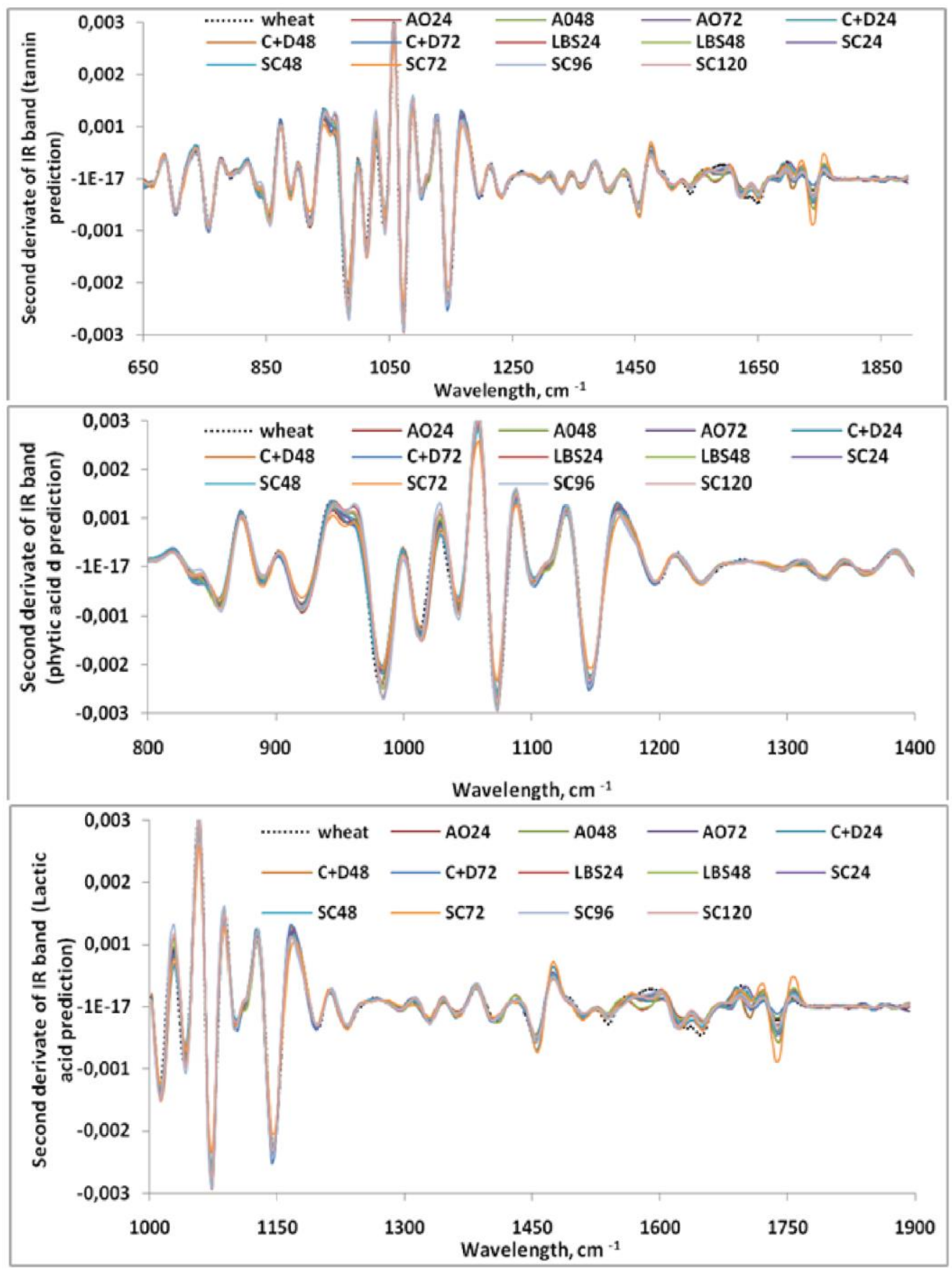

Figure 3. Second derivate of FT-IR spectra data from 650 to $1900 \mathrm{~cm}^{-1}$ subjected to PLSR analysis to predict the chemically analysed tannin (upper), phytic acid (middle) and lactic acid (lower) contents. 


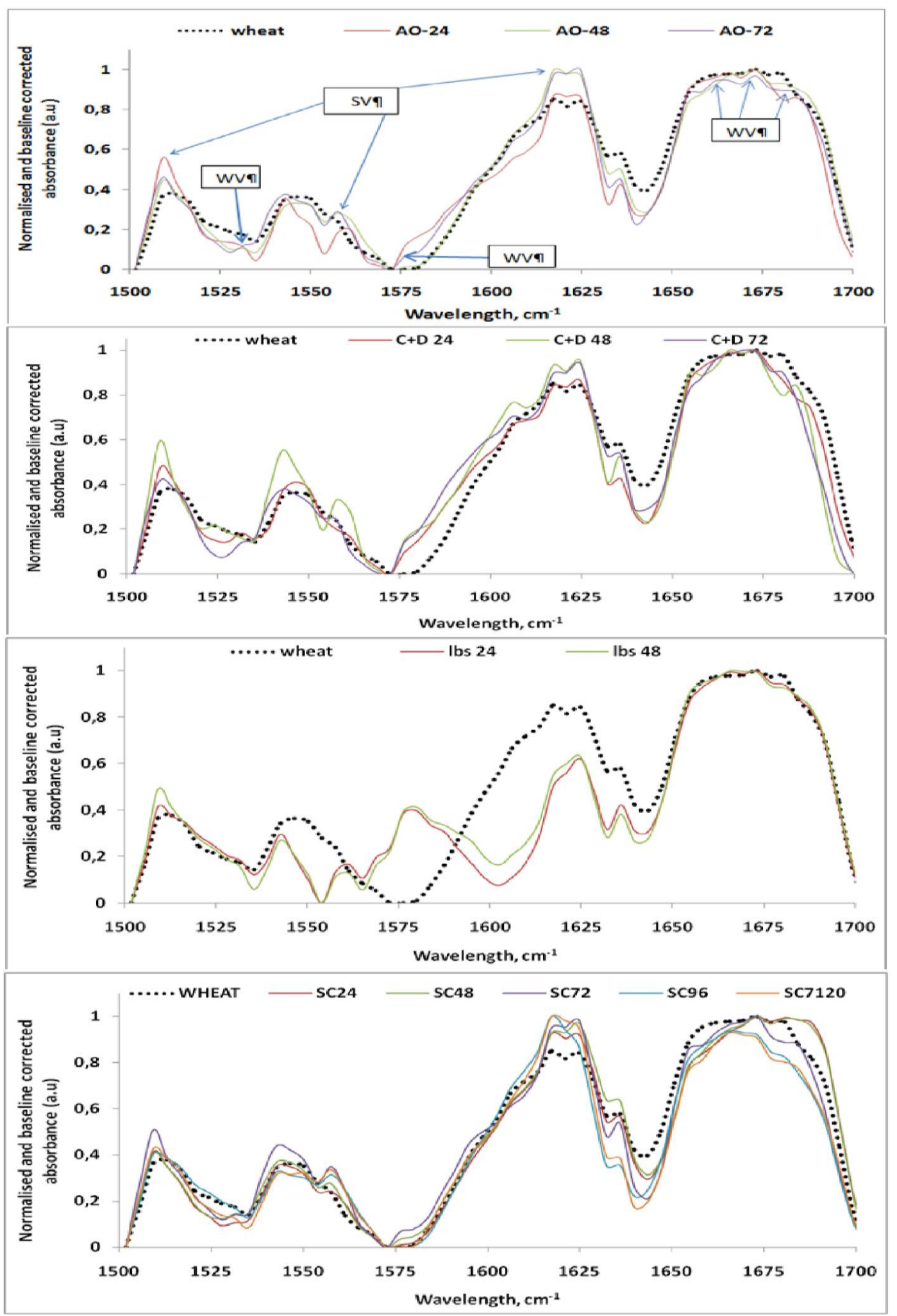

Figure 4. Amide I and amide II spectrum of ground wheat grain by microbial fermentation. $\mathrm{AO}=$ Aspergillus oryzae $\mathrm{C}+\mathrm{D}=\mathrm{AO}+$ Bacillus subtilis; $\mathrm{LBS}=$ Lactobacillus salivarius; $\mathrm{SC}=$ Saccharomyces cerevisiae . $\mathrm{SV}=$ strong vibrations and $\mathrm{WV}=$ weak vibrations were shown by arrows as example in $\mathrm{AO}$ fermentation.

\section{Structural and conformational changes to the native wheat protein by microbial fermentation}

FTIR-ATR widely used to quantify chemical and structural characteristics of a given sample by transitioning vibrational energy (Carbonaro et al., 2012; Wilcox, 2014) was employed in our study to quantify SPC for fermented 
wheat grain. IR spectral range from 1600 to $1700 \mathrm{~cm}^{-1}$ for amide I and 1500 to $1600 \mathrm{~cm}^{-1}$ amide II was a frequently studied region for protein analysis (Salazar-Villanea et al., 2016; Yasar and Tosun, 2018). Differences and similarities in protein specific regions between fermented and unfermented samples can carefully be observed, especially at $1500-1700 \mathrm{~cm}^{-1}$ band to which a normalisation and baseline correction treatment applied (Figure 4). In Figure 2, the changes in amide I and II caused by microbial fermentation was easily differentiated. Usually, there were increased stretching vibrations at peaks around 1512,1542,1620, 1635 and 1650-1690 $\mathrm{cm}^{-1}$ in wheat fermented by AO, C+D and SC as well as two new weak peaks at 1531 and $1557 / 1561 \mathrm{~cm}^{-1}$ bands, compared to unfermented wheat. In fermented wheat by LBS, the changes were more discriminative than the remaining fermented wheat samples (Figure 4). In addition to increased stretching vibrations at $1512 \mathrm{~cm}^{-1}$, two new strong peaks at $1561 \mathrm{~cm}^{-1}$ and $1576 \mathrm{~cm}^{-1}$ were obtained from LBS fermentation of wheat. The quantification of area under peaks of amide I and amide II regions and ratio of amide I:II were determined and compared between the samples. Chemical and physical treatments of cereal grains were shown to affect SPC of amide I, amide II and ratio of amide I:II which may be an indication of differences in nutrient contents of processed forms of a particular food (Yu et al., 2010). The quantified area under amide I and amide II and the ratio of amide I:II markedly differed between unfermented and fermented wheat in our study (Table 3). These parameters were remarkably changed throughout the fermentation period.

Table 3. Structural differences in the area of absorbance for amide I and II bands by microbial fermentation of ground wheat grain

\begin{tabular}{|c|c|c|c|c|c|c|}
\hline \multirow[b]{2}{*}{ Wheat (non-fermented) } & \multicolumn{2}{|c|}{ AMIDE II } & \multicolumn{2}{|c|}{ AMIDE I } & \multirow{2}{*}{$\frac{\Sigma}{\text { Area }}$} & \multirow{2}{*}{$\begin{array}{c}\text { Ratio of } \\
\text { amide I to } \\
\text { amide II }\end{array}$} \\
\hline & Peak area & $\begin{array}{l}\text { Standard } \\
\text { deviation }\end{array}$ & Peak area & $\begin{array}{l}\text { Standard } \\
\text { deviation }\end{array}$ & & \\
\hline Spectral band range, $\mathrm{cm}^{-1}$ & \multicolumn{2}{|c|}{$1500-1570$} & \multicolumn{2}{|c|}{$1570-1700$} & & \\
\hline $\mathbf{0}$ & $16.01^{\mathrm{a}}$ & 0.23 & 78.75a & 0.60 & $\begin{array}{c}94.7 \\
6\end{array}$ & 4.92 \\
\hline \multicolumn{7}{|l|}{$\mathrm{AO}^{*}$} \\
\hline Spectral band range, $\mathrm{cm}^{-1}$ & \multicolumn{2}{|c|}{$1500-1570$} & \multicolumn{2}{|c|}{$1570-1700$} & & \\
\hline 24 & $13.84 \mathrm{~b}$ & 0.19 & $87.96^{a}$ & 0.44 & 101.8 & 6.36 \\
\hline 48 & $15.41 \mathrm{a}$ & 0.21 & $93.83^{\mathrm{b}}$ & 0.47 & 109.2 & 6.09 \\
\hline 72 & $15.64^{\mathrm{a}}$ & 0.22 & $93.11^{\mathrm{b}}$ & 0.46 & 108.7 & 5.95 \\
\hline \multicolumn{7}{|l|}{$\mathrm{C}+\mathrm{D}$} \\
\hline Spectral band range, $\mathrm{cm}^{-1}$ & \multicolumn{2}{|c|}{$1500-1570$} & \multicolumn{2}{|c|}{$1570-1700$} & & \\
\hline 24 & $16.05^{\mathrm{a}}$ & 0.23 & $75.19^{a}$ & 0.57 & 91.24 & 4.68 \\
\hline 48 & $19.26^{c}$ & 0.27 & $76.05^{\mathrm{a}}$ & 0.58 & 95.31 & 3.95 \\
\hline 72 & $14.92^{\mathrm{b}}$ & 0.21 & $77.28^{a}$ & 0.59 & 92.2 & 5.18 \\
\hline \multicolumn{7}{|l|}{ LBS } \\
\hline Spectral band range, $\mathrm{cm}^{-1}$ & \multicolumn{2}{|c|}{$1500-1554$} & \multicolumn{2}{|c|}{$1554-1700$} & & \\
\hline 24 & $11.54^{\mathrm{d}}$ & 0.22 & $69.45^{a}$ & 0.46 & 81.0 & 6.02 \\
\hline 48 & $11.63^{\mathrm{d}}$ & 0.22 & $71.55^{a}$ & 0.47 & 83.2 & 6.15 \\
\hline \multicolumn{7}{|l|}{$\mathrm{SC}$} \\
\hline Spectral band range, $\mathrm{cm}^{-1}$ & \multicolumn{2}{|c|}{$1500-1570$} & \multicolumn{2}{|c|}{$1570-1700$} & & \\
\hline 24 & $14.69^{b}$ & 0.21 & $78.50^{\mathrm{a}}$ & 0.59 & 93.2 & 5.34 \\
\hline 48 & $15.52^{\mathrm{a}}$ & 0.22 & $80.13^{a}$ & 0.61 & 95.6 & 5.16 \\
\hline 72 & $18.13^{c}$ & 0.26 & $76.31^{\mathrm{a}}$ & 0.58 & 94.4 & 4.21 \\
\hline 96 & $16.98^{\mathrm{a}}$ & 0.24 & $71.42^{\mathrm{a}}$ & 0.54 & 88.4 & 4.21 \\
\hline 120 & $16.10^{a}$ & 0.23 & $71.13^{a}$ & 0.54 & 87.2 & 4.42 \\
\hline
\end{tabular}

${ }^{*} \mathrm{AO}=$ Aspergillus oryzae $; \mathrm{C}+\mathrm{D}=\mathrm{AO}+$ Bacillus subtilis; $\mathrm{LBS}=$ Lactobacillus salivarius; $\mathrm{SC}=$ Saccharomyces cerevisiae $;{ }^{\mathrm{a}-\mathrm{d}}=$ Different superscripts indicate significant differences $(\mathrm{P}<0.05)$ between the means of wheat grain over a period of fermentation by each microorganism.

Wheat protein in its native conformation has an absorption area of 78.75 of amide I and of 16.01 of amide II regions with a 4.92 of ratio of amide I:II. AO fermentation changed these conformations, causing an increased area of amide I (87.96 to 93.11) and decreased area of amide II (13.84 to 16.64) with an increased ratio of amide I:II (5.95 to 6.36). The absorption areas of both regions (69 to 71 of amide I and 11.5 to 11.6 of amide II) were markedly reduced by LBS fermentation with an increase of amide I:II ratio (6.02-6.15). However, SC (yeast) and C+D fermentations did not remarkably change the conformation of amide I, but there was a sporadic change in amide II region as well as 
in the ratio of amide I:II,. Moreover, in our study there were no linear or weak relationships estimated by a univariate analysis of Pearson's correlation $\left(r^{2}>0.30\right)$ between the nutrient concentrations and the absorption area of their amide I and II areas and amide I:II ratio of original IR data where no second derivate transformation applied. Despite of univariate test showing high relationship between the protein content and the absorption area of these bands (Yu et al., 2010) the multivariate test based on PLSR using second derivate IR data produced a robust and accurate prediction of all the nutrient concentration in fermented wheat samples in our study. Moreover, the difference in the absorption areas of amide I and II between fermented wheat samples is a good indication of SPC changes which was quantified by FSD and Gaussian curve fitting applications and demonstrated as follows:

The determination of SPC was done by FTIR-ATR spectroscopy from 1600 to $1700 \mathrm{~cm}^{-1}$, called as "amide I region". The method is made simple by detecting the vibrations of carboxyl groups of amino acids (Carbonaro et al., 2012; Yasar and Tosun, 2018). All FTIR spectra of amide I region revealed a clear resolution can be seen in Figure 4, where the differences in SPC evidential. But, an FSD illustration (Figure 6) showed a native protein structure of unfermented wheat sample which was completely changed during microbial fermentations (Figure 5).

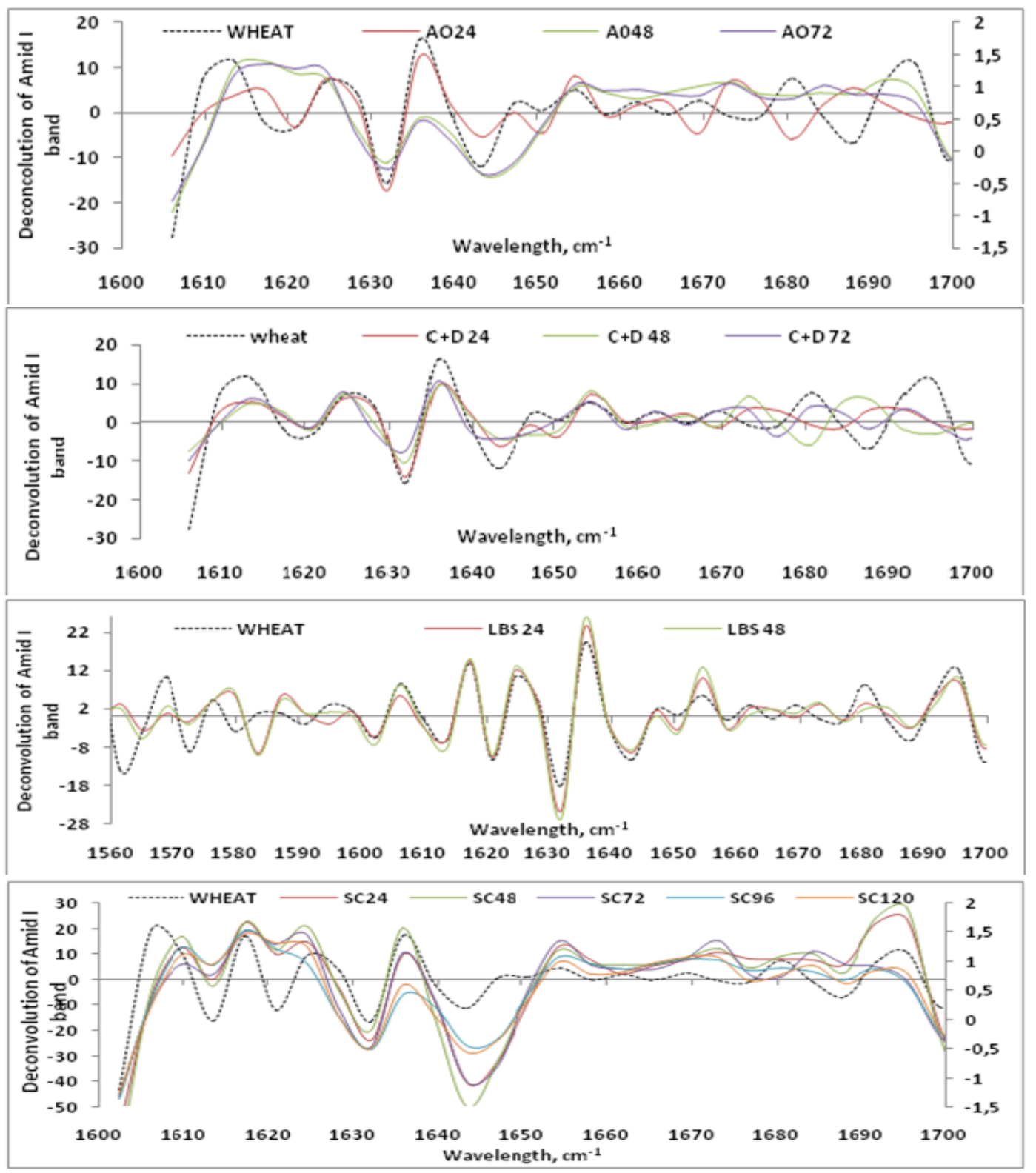

Figure 5. FSD of FT-IR spectral band (asymmetric baseline correction and rescaling applied) of amide I regions of fermented ground wheat grains by several microorganisms.AO = Aspergillus oryzae $; \mathrm{C}+\mathrm{D}=\mathrm{AO}+$ Bacillus; $\mathrm{LBS}=$ Lactobacillus salivarius; $\mathrm{SC}=$ Saccharomyces cerevisiae. FSD spectrum is shown, as obtained with a bandwidth $=4 \mathrm{~cm}^{-1}$ and a resolution enhancement factor $=2$. Thin dashed horizontal line indicates the spectral band of unfermented grain wheat sample at $0 \mathrm{~h}$ of fermentation 
Furthermore, the quantification of SPC of wheat samples by the method of Gaussian curve fitting followed by FSD (an example of unfermented wheat sample provided in Figure 6) was provided in Table 4. These differences in SPC were expected since the microbial fermentation has several enzymatic (microbial or activated plant endogenous origins), chemical ( $\mathrm{pH}$ ) and physical treatments (stirring and aeration) which were previously shown to have affected the protein structure (Yu et al., 2010 and Yasar et al., 2020).

Table 4. Percentages of the secondary structure components (\% of amide I band) as predicted by Gaussian fitting of deconvolution of the amide I bandsof ground wheat grain by microbial fermentation.

\begin{tabular}{|c|c|c|c|c|c|c|c|c|c|c|c|c|c|c|c|}
\hline \multirow{2}{*}{$\begin{array}{c}\text { Microorganisms } \\
\text { Incubation, h }\end{array}$} & \multicolumn{2}{|c|}{ Wheat } & \multicolumn{3}{|c|}{ AO } & \multicolumn{2}{|c|}{$C+D$} & \multicolumn{3}{|c|}{ LBS } & \multicolumn{2}{|c|}{ SC } & \multicolumn{3}{|c|}{ SEM } \\
\hline & $\mathbf{0}$ & 24 & 48 & 72 & 24 & 48 & 72 & 24 & 48 & 24 & 48 & 72 & 96 & 120 & \\
\hline $\mathrm{S}\left(1560-1610^{*}\right)$ & & & & & & & & 27.6 & 26.45 & & & & & & 0.01 \\
\hline A1(1610-1615) & $26.98^{a}$ & $29.4^{b}$ & $21.55^{c}$ & $18.38^{\mathrm{d}}$ & $25.88^{a}$ & $23.17^{c}$ & $25.06^{\mathrm{a}}$ & $13.26^{\mathrm{e}}$ & $16.18^{\mathrm{f}}$ & $18.78 \mathrm{~g}$ & $19.62^{g}$ & $18.94 \mathrm{~g}$ & $21.00^{c}$ & $19.79 \mathrm{~g}$ & 0.15 \\
\hline A2 (1690-1695) & $11.43^{\mathrm{a}}$ & $0.49^{b}$ & $13.46^{c}$ & $14.4^{\mathrm{d}}$ & $3.83^{\mathrm{e}}$ & $1.55^{\mathrm{f}}$ & $6.19 \mathrm{~g}$ & $9.58^{\mathrm{h}}$ & $8.49^{\mathrm{h}}$ & $15.37^{\mathrm{i}}$ & $14.50^{\mathrm{j}}$ & $9.53^{\mathrm{h}}$ & $9.35^{\mathrm{h}}$ & $10.11^{\mathrm{k}}$ & 0.05 \\
\hline$\beta(1630-1640)$ & $10.93^{a}$ & $11.68^{b}$ & $9.76^{c}$ & $8.9^{d}$ & $16.97 \mathrm{e}$ & $15.49^{\mathrm{f}}$ & $20.3 \mathrm{~g}$ & $9.56^{c}$ & $11.04^{b}$ & $11.48^{\mathrm{b}}$ & $11.87 \mathrm{~b}$ & $11.50^{\mathrm{b}}$ & $17.38^{\mathrm{h}}$ & $18.21^{\mathrm{i}}$ & 0.01 \\
\hline$\beta-i(1620-1630)$ & $16.74^{\mathrm{a}}$ & $19.06^{b}$ & $20.9^{b}$ & $22.18^{c}$ & $16.26^{\mathrm{a}}$ & $16.83^{a}$ & $17.7^{a}$ & $10.6^{\mathrm{d}}$ & $12.63^{\mathrm{e}}$ & $10.29^{d}$ & $10.57^{d}$ & $10.58^{\mathrm{d}}$ & $8.41^{\mathrm{f}}$ & $8.35^{f}$ & 0.43 \\
\hline$\beta$-a (1680-1688) & $0.00^{\mathrm{a}}$ & $6.53^{\mathrm{b}}$ & $6.35^{\mathrm{b}}$ & $7.10^{c}$ & $4.98^{\mathrm{d}}$ & $11.57 \mathrm{e}$ & $8.65^{f}$ & $8.10^{\mathrm{f}}$ & $5.25^{\mathrm{d}}$ & $10.33^{e}$ & $5.02^{\mathrm{d}}$ & $10.46^{\mathrm{e}}$ & $9.41^{\mathrm{e}}$ & $9.67 \mathrm{e}$ & 0.20 \\
\hline Total $\beta$-sheet conformations & $27.67 \mathrm{a}$ & $37.27 \mathrm{~b}$ & $37.01^{\mathrm{b}}$ & $38.18^{\mathrm{b}}$ & $38.21^{\mathrm{b}}$ & $43.89^{c}$ & $46.65^{\mathrm{d}}$ & $28.26^{\mathrm{a}}$ & $28.92^{\mathrm{a}}$ & $32.10^{\mathrm{e}}$ & $27.47^{a}$ & $32.54 \mathrm{e}$ & $35.19^{\mathrm{f}}$ & $36.23 \mathrm{~g}$ & 0.03 \\
\hline RC (1640-1648) & $6.34^{\mathrm{a}}$ & $5.44 \mathrm{~b}$ & $2.16^{c}$ & $1.99 \mathrm{c}$ & $4.36^{\mathrm{d}}$ & $3.06^{\mathrm{e}}$ & $2.25^{\mathrm{c}}$ & $3.85^{\mathrm{f}}$ & $3.93^{\mathrm{f}}$ & $1.96^{\mathrm{c}}$ & $2.26^{c}$ & $0.67 \mathrm{~g}$ & $2.00^{c}$ & $1.87^{\mathrm{c}}$ & 0.01 \\
\hline $\begin{array}{c}\alpha \text {-helix } \\
(1650-1660)\end{array}$ & $6.74 \mathrm{a}$ & $8.09 \mathrm{~b}$ & $11.71^{\mathrm{c}}$ & $12.41^{\mathrm{d}}$ & $11.37 \mathrm{c}$ & $12.48^{\mathrm{d}}$ & $6.28^{a}$ & $5.21 \mathrm{e}$ & $7.27^{f}$ & $15.60 \mathrm{~g}$ & $15.48 \mathrm{~g}$ & $16.62^{\mathrm{h}}$ & $15.91 \mathrm{~g}$ & $9.82^{\mathrm{i}}$ & 0.03 \\
\hline $\begin{array}{c}\beta-\mathrm{T} 1 \\
(1660-1670)\end{array}$ & $10.76^{\mathrm{a}}$ & $9.51^{b}$ & $6.98^{c}$ & $7.14^{\mathrm{d}}$ & $8.23^{e}$ & $8.65^{e}$ & $9.00^{\mathrm{b}}$ & $8.06^{\mathrm{e}}$ & $5.36^{\mathrm{f}}$ & $10.61^{\mathrm{a}}$ & $10.18^{\mathrm{a}}$ & $10.72^{\mathrm{a}}$ & $11.13 \mathrm{~h}$ & $16.53^{\mathrm{i}}$ & 0.02 \\
\hline $\begin{array}{c}\beta-\mathrm{T} 2 \\
(1670-1680)\end{array}$ & $10.08^{a}$ & $9.80^{\mathrm{b}}$ & $7.13^{\mathrm{c}}$ & $7.50^{\mathrm{c}}$ & $8.12^{\mathrm{d}}$ & $7.20^{\mathrm{c}}$ & $4.57 \mathrm{e}$ & $4.18^{e}$ & $3.40^{\mathrm{f}}$ & $5.57 \mathrm{~g}$ & $10.50^{\mathrm{a}}$ & $10.98^{a}$ & $5.41 \mathrm{~g}$ & $5.64 \mathrm{~g}$ & 0.05 \\
\hline$\alpha$-helix: $\beta$-sheet ratio & $24.36^{a}$ & $21.71^{\mathrm{b}}$ & $31.64^{c}$ & $32.50^{c}$ & $29.76^{\mathrm{d}}$ & $28.43^{\mathrm{d}}$ & $13.46^{\mathrm{e}}$ & $18.44^{\mathrm{f}}$ & $25.14^{a}$ & $48.58 \mathrm{~g}$ & $56.3^{\mathrm{h}}$ & $51.09 \mathrm{~h}$ & $45.22 \mathrm{~g}$ & $27.10^{\mathrm{d}}$ & 0.001 \\
\hline
\end{tabular}

$\mathrm{S}=$ side chains; $\mathrm{A} 1$ and $\mathrm{A} 2=$ protein aggregates and absorption of amino acid-side chain; $\beta=$ beta-sheet protein structure; $\beta$-i $=$ intermolecular beta-sheet; $\beta$-a $=$ antiparallel beta-sheet; $\alpha$-helix $=\alpha$-helix protein structure; $\beta$-T1 and $\mathrm{T} 2=$ beta-turn conformations. $\mathrm{AO}=$ Aspergillus oryzae; $\mathrm{C}+\mathrm{D}=\mathrm{AO}+$ Bacillus subtilis; $\mathrm{LBS}=$ Lactobacillus salivarius; $\mathrm{SC}=$ Saccharomyces cerevisiae. $* \mathrm{FT}-\mathrm{IR}$ spectral band intervals

$\left(\mathrm{cm}^{-1}\right)$ reported for each secondary structural component. SEM = standard error of the means. a-k $^{-}$Different superscripts indicate significant differences $(\mathrm{P}<0.05)$ between the means of analysed constituents of ground wheat grain over a period of fermentation by each microorganisms.

In our study the temperature $\left(24-28^{\circ} \mathrm{C}\right)$ and pH (almost around 5.0) are rather considered beneficial on SPC since microbial fermentation produced some metabolites such as enzymes and probiotics which are of nitrogenous nature interfering with $\alpha$-helix domination of amide I. Therefore, the changes observed in SPC from 1600 to $1700 \mathrm{~cm}^{-1}$ could be more related to the presence of probiotics or generation of new bio-molecules (enzymes, antioxidant and organic acids) by microbial fermentation. These results were also confirmed by our previous study (Yasar and Tosun, 2018 and Yasar et al., 2020). The degree of such nutrient fortification and increased bio-functional molecules associated with SPC changes of wheat were highly depending on the type of microorganisms used in this study. Therefore, the increased percentages of $\beta$-sheet and $\alpha$-helix and an increased ratio of $\alpha$-helix to $\beta$-sheet could be considered beneficial in terms of the fortification of wheat grain with bio-functional molecules. In our study, the latter ratio was almost increased by microbial fermentation, with an exception of $24 \mathrm{~h}$ of LBS, $24 \mathrm{~h}$ of AO and $48 \mathrm{~h}$ 
of $\mathrm{C}+\mathrm{D}$. Moreover, total $\beta$-sheet and $\alpha$-helix conformations were increased up to 68 and $140 \%$ by the microbial fermentation, respectively. The change in $\beta$-turn formations in our study occurred to a lesser degree. Moreover, intramolecular antiparallel $\beta$-sheet component $(\beta-a)$ was introduced in fermented wheat samples, which was not found in unfermented wheat. A remarkable aggregation at the side chains (S) below $1610 \mathrm{~cm}^{-1}$ was only obtained

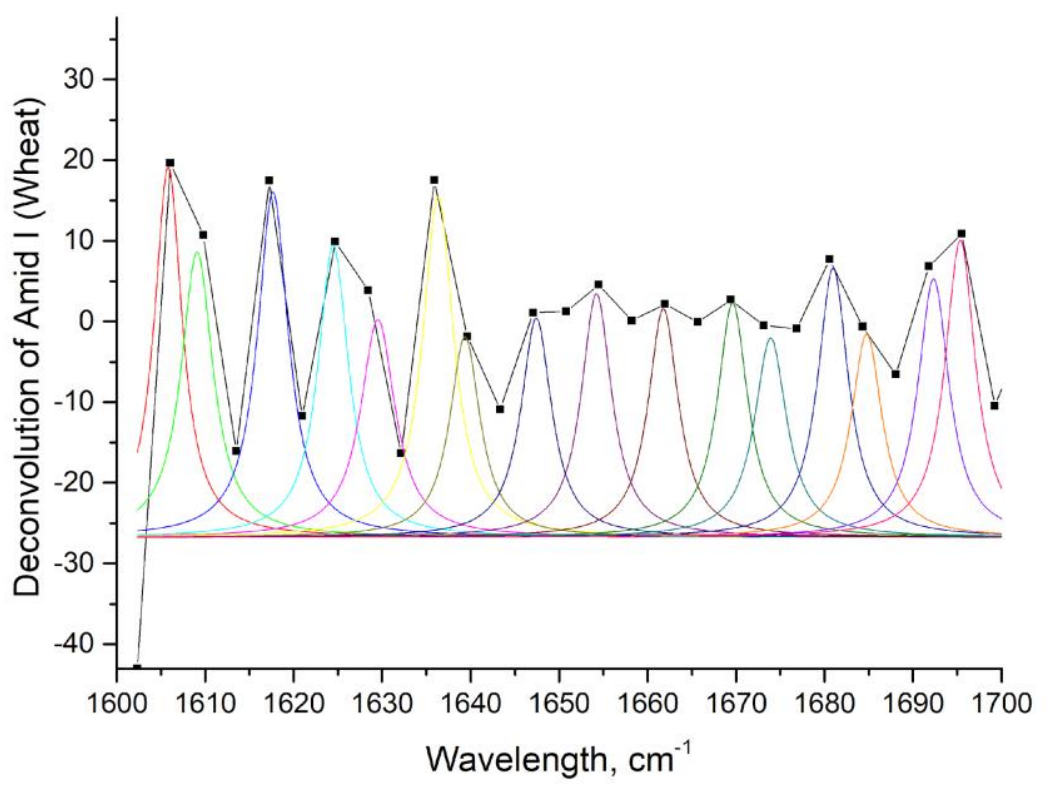

Figure 6. FSD of amide I spectral band with Gaussian contributions (asymmetric baseline correction and re-scaling applied) to predict secondary protein components: an example of non-fermented ground wheat grain. FSD spectrum shown with black line obtained with a bandwidth $=4 \mathrm{~cm}^{-1}$ and a resolution enhancement factor $=2$.

from LBS fermentation as an indication of increased smaller molecular weight protein which is readily soluble. The changes in remaining components (A1 and $\beta$ ) of fermented wheat samples were not to a large extent. According to the results of Salazar-Villanea et al. (2016) any changes to native protein conformation in the form of denaturation or unfolded (random coil) formation is considered as positive, while the formation of Maillard reactions in terms of protein digestibility is considered as negative. In contrast, no Maillard reactions were seen in these fermented wheat samples since the samples were dried under $50{ }^{\circ} \mathrm{C}$ and there was no increase in the percentage of random coil. Contrary, the random coil was denatured about $63 \%$ by almost all the microbial fermentations, indicating the beneficial effects of fermenting wheat grain (increased smaller molecular weight protein). Such denaturation may be responsible for the reduced crude protein concentration in $\mathrm{C}+\mathrm{D}$ and SC fermentations since these microorganisms may have needed additional nitrogen for growth. Overall, microbial fermentation induced significant changes in wheat SPC which could be related to not only changed protein concentration in some fermentations, but also nutritional fortification of wheat grain (probiotic, enzymes, antioxidants, organic acids and reduced ANF) in all fermentations. And, the latter was confirmed by ANF reduction and enrichment with lactic acid.

As overall, it was previously shown that similar chemometric approaches using different multivariate methods such as hierarchical cluster analysis and principal component analysis coupled to certain parts of fingerprint region of entire wheat FTIR-ATR spectra successfully differentiated several cultivars of wheat grain (Demir et al., 2015) and structural differences in carbohydrate features of different types of cereal grains and legumes (Kurdziel et al., 2019; Rahman et al., 2019). Herein we employed another multivariate technique, PLSR which produced a robust measurement of wheat nutrient contents. Our results demonstrated that the samples of wheat subjected to microbial fermentation involving heat, $\mathrm{pH}$ and stirring treatments can be effectively differentiated from each other by the FTIR-ATR spectroscopy coupled to chemometry using specific bands from the fingerprint region. The part of Amid I in this fingerprint region is used to reveal SPC of the protein, and the criteria of analysis of these protein components were previously well defined (Mäntele, 2015) and were also confirmed within our study (see section 2.4). Therefore, we recommended that the FSD analysis of Amide I region is a valid procedure to reveal SPC in wheat samples, and herein the mentioned procedure and criteria laid down elsewhere (Mäntele, 2015) can widely be used. 


\section{CONCLUSIONS}

The method developed and tested in the present study provides a fast and robust way to determine the nutritional composition of fermented wheat samples by FTIR-ATR spectroscopy using specific spectra fingerprint regions and to reveal changes on the secondary protein structure by microbial fermentation, and is recommended to be applied in fermentation technology industry.

\section{Acknowledgement}

This study was supported by the Scientific and Technological Research Council of Turkey (TUBITAK- grand number: 2140629) to conduct fermentation studies.

\section{Conflicts of Interest}

The authors declare that they do not have any conflict of interest.

\section{REFERENCES}

1. AOAC (Association of Official Analytical Chemists). Official Methods of Analysis. 20 ${ }^{\text {th }}$ ed., Washington DC, USA; 2016.

2. Adebo OA, Njobeh PB, Kayitesi E. Fermentation by Lactobacillus fermentum strains (singly and in combination) enhances the properties of ting from two whole grain sorghum types. J Cereal Sci. 2018; 82:49-56.

3. Azza AM, Samia El-Safy F, Eman HFA. Improvement of nutritional quality and antioxidant activities of fermented wastes by Saccharomyces cervisiae, Bacillus subtilis and Pleurotus salmoneo-stramineus. Proceedings of $3^{\text {rd }}$ International Conference on Biotechnology and its applications in Botany and Microbiology, 2013 April 17-18, Cairo, Egypt.

4. Batista NN, Ramos CL, de Figueiredo Vilela L, Dias DR, Schwan RF. Fermentation of yam (Dioscorea spp. L.) by indigenous phytase-producing lactic acid bacteria strains. Braz J Microbiol. 2019; 2:507-14. doi: 10.1007/s42770-019-00059-5.

5. Cabuk B, Nosworthy MG, Stone AK, Korber DR, Tanaka T, House JD, Nickerson MT. Effect of fermentation on the protein digestibility and levels of non-nutritive compounds of pea protein concentrate. Food Techn Biotech. 2018; 56:257-64. Doi:10.17113/ftb.56.02.18.5450.

6. Carbonaro M, Maselli P, Nucara A. Relationship between digestibility and secondary structure of raw and thermally treated legume proteins: a Fourier transform infrared (FT-IR) spectroscopic study. Amino Acids. 2012; 43:911-21. Doi:10.1007/s00726-011-1151-4.

7. Chemesova II, Chizhikov DV. Determination of tannin content in rhizomes of Comarum palustre L. and its tincture by spectrophotometric method. Rastit Resur. 2004; 40:122-30.

8. Dave G, Modi H. FT-IR method for estimation of phytic acid content during bread-making process. J Food Meas Charact. 2018; 12:2202-8. Doi.org/10.1007/s11694-018-9836-y.

9. De Boland AR, Garner GB, o Dell BL. Identification and properties of phytate in cereal grains and oil seed products. J Agric Food Chem. 1975; 23:1186-9. Doi.org/10.1021/jf60202a038.

10. Demir P, Onde S, Severcan F. Phylogeny of cultivated and wild wheat species using ATR-FTIR spectroscopy. Spectrochim Acta A Mol Biomol Spectrosc. 2015; 135:7570-63. Doi.org/10.1016/j.saa.2014.07.025.

11. Ferrao MF, Celso U, Davanzo CU. Horizontal attenuated total reflection applied to simultaneous determination of ash and protein contents in commercial wheat flour. Anal Chim Acta. 2005; 540:411-41.

12. Ishiguro $\mathrm{T}$, Ono T, Nakasato $\mathrm{K}$, Tsukamoto $\mathrm{C}$, Shimada $\mathrm{S}$. Rapid measurement of phytate in raw soymilk by midinfrared spectroscopy. Biosci Biotechnol Biochem. 2003; 4:752-7. doi: 10.1271/bbb.67.752. PMID: 12784614.

13. Karabulut A, Canbolat O. Feed Evaluation and Analysis Methods. Uludag University Publication, Bursa, Turkey; 2005.

14. Karakurt Y, Guvercin D, Onder S, Celik C, Tosun R, Baran B, Yasar S. Chemical, enzymatic, and antioxidant enrichments of full-fat soybean and sunflower meal by Bacillus subtilis (ATCC® $6633^{\mathrm{TM}}$ ) fermentation using a solid-state bioreactor. Turk J Vet Anim Sci. 2019; 43:82-93. Doi:10.3906/vet-1803-1.

15. Kim J, Hwang K, Lee S. ACE Inhibitory and hydrolytic enzyme activities in textured vegetable protein in relation to the solid state fermentation period using Bacillus subtilis HA. Food Sci Biotechnol. 2010; 19:487-95. Doi:10.1007/s10068-010-0068-0.

16. Krishna CH. Solid-state fermentation systems- an overview. Crit Rev Biotechnol. 2005; 25:1-30. Doi.10.1080/07388550590925383.

17. Kurdziel M, Łabanowska M, Pietrzyk S, Sobolewska-Zielińska J, Michalec M. Changes in the physicochemical properties of barley and oat starches upon the use of environmentally friendly oxidation methods. Carbohydr Polym. 2019; 210:339-49. Doi.org/10.1016/j.carbpol.2019.01.088.

18. Lopez HW, Ouvry A, Bervas E, Guy C, Messager A, Demigne C, Remesy C. (2000). Strains of lactic acid bacteria isolated from sour doughs degrade phytic acid and improve calcium and magnesium solubility from whole wheat flour. J Agric Food Chem., 6, 2281-2285. doi: 10.1021/jf000061g. 
19. Mahazar SA, Kandhro AA, Cerretani L, Bendini A, Sherazi ATH, Bhanger MI. Determination of total trans fat content in Pakistani cereal-based foods by SB-HATR FT-IR spectroscopy coupled with partial least square regression. Food Chem. 2010; 123:1289-93. doi:10.1016/j.foodchem.2010.05.101.

20. Mäntele W. The analysis of protein conformation by infrared spectroscopy: An introduction of the editor to a scientific dispute. Spectrochim. Acta A Mol Biomol Spectrosc. 2015; 138:964-6. Doi.org/10.1016/j.saa.2014.11.022.

21. Mohapatra PKD, Mondal KC, Pati BR. Production of tannase through submerged fermentation of tannin containing plant extracts by Bacillus licheniformis KBR6. Pol J Microbiol. 2006; 55:297-301.

22. Moreira JL, Santos L. Analysis of organic acids in wines by Fourier-transform infrared spectroscopy. Anal Bioanal Chem. 2005; 382:421-5. Doi.org/10.1007/s00216-005-3062-2.

23. Rahman MM, Feng X, Zhang H, Yan X, Peng Q, Yu P. Using vibrational ATR-FTIR spectroscopy with chemometrics to reveal faba $\mathrm{CHO}$ molecular spectral profile and $\mathrm{CHO}$ nutritional features in ruminant systems. Spectrochim. Acta A Mol Biomol Spectrosc. 2019; 214:269-76. Doi.org/10.1016/j.saa.2019.02.011.

24. Raghavendra and Halami. Screening, selection and characterization of phytic acid degrading lactic acid bacteria from chicken intestine. Int J Food Microbiol. 2009; 133(1-2):129-34. https://doi.org/10.1016/j.ijfoodmicro.2009.05.006.

25. Rubio LA, Pérez A, Ruiz R, Guzman MA, Aranda-Olmedo I, Clemente A. Characterization of pea (Pisum sativum) seed protein fractions. J Sci Food Agric. 2014; 94:280-7. Doi:10.1002/jsfa.6250.

26. Salazar-Villanea S, Hendriks WH, Bruininx EM, Gruppen H, van der Poel AF. Protein structural changes during processing of vegetable feed ingredients used in swine diets: Implications for nutritional value. Nutr Res Rev. 2016; 29:126-41. Doi:10.1017/S0954422416000056.

27. Santos MM, Rosa AS, Dal'boit S, Mitchell DA, Kriger N. Thermal denaturation: is solid-state fermentation really a good technology for the production of enzymes. Bioresour Technol. 2004; 93:261-8. Doi.10.1016/j.biortech.2003.11.007.

28. Sarwar Gilani G, Wu Xiao C, Cockell KA. Impact of antinutritional factors in food proteins on the digestibility of protein and the bioavailability of amino acids and on protein quality. Br J Nutr. 2012; 108:315-32. Doi:10.1017/S0007114512002371.

29. Silverstein RM, Bassler GC, Morrill TC. Spectrometric identification of organic compounds. $5^{\text {th }}$ ed. Wiley, New York; c1991.

30. TS EN ISO 15787:2009. Animal feedstuffs - Lactobacillus spp. Isolation and enumeration. Turkish Standardization Institute. Necatibey Caddesi No.112 Bakanliklar / Amkara. 2009.

31. TS EN ISO 15788:2009. Animal feeds - Separation and enumeration of yeast probiotic strains. Turkish Standardization Institute. Necatibey Caddesi No.112 Ministries / Ankara. 2009.

32. TS ISO 21527-1:2008. Food and animal feed microbiology - Horizontal method for counting yeast and molds Part 1: Colony count technique for products with water activity higher than 0.95. Turkish Standardization Institute. Necatibey Caddesi No.112 Ministries / Ankara. 2008.

33. TS ISO 21527-2:2008. Food and animal feed microbiology - Horizontal method for counting yeasts and molds Part 2: Colony count technique for products with water activity equal to or less than 0.95. Turkish Standardization Institute. Necatibey Caddesi No.112 Ministries / Ankara. 2008.

34. Wilcox KE. Using regression analyses for the determination of protein structure from FTIR spectra. PhD Thesis. UK, The University of Manchester, the Faculty of Life Sciences; 2014.

35. Wubshet SG, Måge I, Böcker U, Lindberg D, Knutsen SH, Rieder A, Rodriguez DA, Afseth NK. FTIR as a rapid tool for monitoring molecular weight distribution during enzymatic protein hydrolysis of food processing byproducts. Anal Methods. 2017; 9:4247-54. Doi:10.1039/C7AY00865A.

36. Udén P, Sjaunja LO. Estimating volatile fatty acid concentrations in rumen samples by Fourier transform midIR transmission spectroscopy. Anim Feed Sci Technol. 2009; 152:123-32. doi:10.1016/j.anifeedsci.2009.04.002

37. Yasar S, Alma MH, Tosun R, Salan T. Improved by KCL dilution predictive ability of ATR-FTIR spectroscopy determining nutrient contents of sunflower meal. J Anim Feed Sci. 2019; 28:282-90. Doi.org/10.22358/jafs/110419/2019.

38. Yasar S, Tosun R. Predicting chemical, enzymatic and nutritional properties of fermented barley (Hordeum vulgare L.) by second derivate spectra analysis from attenuated total reflectance-Fourier transform infrared data and its nutritional value in Japanese quails. Arch Anim Nutr. 2018; 72:407-23. Doi.org/10.1080/1745039X.2018.1500242.

39. Yasar S, Tosun R. Increased organic acid production and decreased phytate phosphorus by high level of water content of Bacillus subtilis ATCC PTA-6737 fermentation of soybean meal. Bull Univ Agric Sci Vet Med. 2019; 76:1-6. Doi.org/10.15835/buasvmcn-asb:2018.0007.

40. Yasar S, Tosun R, Sonmez Z. Fungal fermentation inducing improved nutritional qualities associated with altered secondary protein structure of soybean meal determined by FTIR spectroscopy. Measurement. 2020; 161:107895. DOI: 10.1016/j.measurement.2020.107895 
41. Yu P, Niu Z, Damiran D. Protein molecular structures and protein fraction profiles of new coproducts from bioethanol production: a novel approach. J Agric Food Chem. 2010; 58:3460-4. Doi:10.1021/jf904179m.

42. You-ling G, Cai-sheng W, Qiu-hua Z, Guo-ying Q. Optimization of Solid-State Fermentation with Lactobacillus brevis and Aspergillus oryzae for Trypsin Inhibitor Degradation in Soybean Meal. J Integr Agric. 2013; 12(5)869-76.

43. Zhang ST, Shi Y, Zhang S, Shang W, Gao X, Wang H. Whole soybean as probiotic lactic acid bacteria carrier food in solid-state fermentation. Food Control. 2014; 41:1-6.

44. Zhang N, Li D, Zhang X, Shia Y, Wang HK. Solid-state fermentation of whole oats to yield synbiotic food rich in lactic acid bacteria and prebiotics. Food Funct. 2015; 6:2620-5. Doi:10.1039/c5fo00411j.

45. Zhong-Tao S, Lin-Mao T, Cheng L, Jin-Hua D. Bioconversion of apple pomace into a multienzyme bio-feed by two mixed strains of Aspergillus niger in solid state fermentation. Electron J Biotechn. 2009; 12:1-9. Doi:10.2225/vol12-issue1-fulltext-1. 